\title{
Vitamin D status in cord blood and newborns: ethnic differences
}

\author{
Francesco Cadario ${ }^{1,2}$, Silvia Savastio ${ }^{1}$, Erica Pozzi ${ }^{1}$, Antonella Capelli', Elena Dondi ${ }^{1}$, Miriam Gatto', \\ Mauro Zaffaroni ${ }^{1}$ and Gianni Bona ${ }^{1}$
}

\begin{abstract}
Background: A deficiency in vitamin D (25OHD) is common throughout the world in both adults and children, being related to skin pigmentation, sun exposure, dietary intake and obesity. Limited data are available for the neonatal age. The aim of the study is to understand the differences in 25OHD levels with respect to skin colour and ethnicity in newborns.

Methods: We randomly enrolled 62 neonates, born at term and appropriate for gestational age. Thirty two were born from Italian mothers with fair skin (FS) and 30 from non-Caucasian mothers (North African, African, Asian and Latin American): 10 with light olive/light brown (LOB) and 20 with medium brown/black skin (MBB). Vitamin D was measured in the cord blood at birth and in neonatal serum during metabolic screening.

Results: $250 \mathrm{HD}$ levels were (mean \pm SD) $21.4 \pm 11 \mathrm{ng} / \mathrm{ml}$ in cord blood and $14.9 \pm 7 \mathrm{ng} / \mathrm{ml}$ in serum after birth. $25 \mathrm{OHD}$ values were higher in cord blood $(p<0.01)$ and neonatal serum $(p<0.001)$ in subjects supplemented with Vitamin D. Newborn FS showed higher vitamin D levels in cord blood when compared to LOB and MBB $(p<0.01)$, and higher levels in neonatal serum when compared to LOB $(p<0.01)$. In cord blood, 25OHD levels were higher in Italian newborns than in North African $(p<0.004)$ and African $(p<0.01)$. In neonatal serum, 25OHD levels were higher in Italian infants only when compared with North African infants $(p<0.03)$.

Conclusions: The present study shows a high prevalence of vitamin D insufficiency and deficiency in newborns with significant differences observed to be due to ethnicity, skin colour and maternal supplementation during the pregnancy.
\end{abstract}

Keywords: Vitamin D, Newborn, Ethnicity, Skin colour

\section{Background}

Vitamin D is a steroid hormone with multiple actions on most tissues in the body. It comes in two forms: ergocalciferol (vitamin D2) present in plants and specific types of fish and cholecalciferol (vitamin D3), synthesized in the skin by 7-dehydrocholesterol through UV radiation. Vitamin D3 is the main source of vitamin D for humans. Vitamin D that comes from the skin or diet is biologically inert and must be first hydroxylated in the liver (25OHD), with a further hydroxylation in the kidney $(1,25 \mathrm{OH} 2 \mathrm{D})$ to be biologically active. Circulating

\footnotetext{
* Correspondence: francesco.cadario@maggioreosp.novara.it

${ }^{1}$ Division of Pediatrics, Department of Health Sciences, University of

Piemonte Orientale, Novara, Italy

${ }^{2}$ IRCAD, (Interdisciplinary Research Center of Autoimmune Diseases), Novara, Italy
}

$25 \mathrm{OHD}$ is the major circulating form of vitamin $\mathrm{D}$ and is considered as the primary indicator of vitamin $\mathrm{D}$ status [1].

$1,25 \mathrm{OH} 2 \mathrm{D}$ stimulates intestinal calcium absorption and regulates this function in a wide number of other tissues. Moreover, vitamin D is a modulator of the innate and adaptive immune system and prospective observational studies suggest that vitamin D supplements in infancy and early childhood may decrease the incidence of chronic diseases such as type 1 diabetes mellitus [1,2]. Current data within the literature demonstrates a high prevalence of vitamin D insufficiency not only in adult and in children, but also in pregnant women and in their neonates [3-5]. Risk factors for vitamin D deficiency and rickets in early life include breast-feeding without vitamin D supplementation, dark skin pigmentation, season,

\section{Biomed Central}


latitude and maternal vitamin D deficiency [1]. The latest guidelines define as insufficient serum levels below $30 \mathrm{ng} / \mathrm{mL}$ (72.5 nmol/liter) and as deficient, levels below $20 \mathrm{ng} / \mathrm{mL}$ (50 nmol/liter) in both adults and children [1-6]. To date, specific range for neonates is not available.

In utero, the fetus is wholly dependent on the mother for vitamin $\mathrm{D}$. The $25 \mathrm{OHD}$ crosses the placenta into the blood stream of the fetus with a half-life of approximately 2 months [7]. However, most pregnant women are vitamin $\mathrm{D}$ deficient or insufficient with a consequential deficiency or insufficiency in their neonates [5-8]. Bodnar et al. [9], in a study of 200 white and 200 black mother-infant pairs, reported that more than $50 \%$ of mothers and newborns had a vitamin D insufficiency, despite the use of multivitamins in pregnancy. Population studies in Europe have shown that immigrants from Asia, the Middle East or Africa have a greater risk of low vitamin D levels [10-12]. Moreover, some studies indicate that ethnic differences play a role in the circulating levels of serum vitamin D [13-15]. Dark-skinned individuals require a greater duration of exposure (4-5 times) than their light-skinned counterparts to synthesise comparable amounts of vitamin D [16]. Country of origin, genetic traits and cultural behaviour are important factors in determining vitamin D levels [17].

Currently, the literature shows that neonatal vitamin D status at birth is highly correlated with maternal vitamin storage. Data suggests that doses exceeding $1000 \mathrm{IU}$ of vitamin $\mathrm{D}$ per day are necessary to achieve sufficienct 25OHD concentrations in pregnant women [18]. Discordant data are present with respect to the role of vitamin D supplementation during pregnancy. Supplementation with D3 instead of D2 has greater efficacy in raising circulating 25OHD concentrations, but only few studies show statistically significant differences in cord blood 25OHD levels between infants of mothers supplemented versus nonsupplemented. Further, multivitamin use during pregnancy has been demonstrated to not be sufficient to correct preexisting maternal vitamin D deficiency [19-22].

In order to understand the differences in vitamin $\mathrm{D}$ levels depending on skin colour and ethnic differences, we evaluated 25OHD levels at birth in cord blood and in the first three days of life from ethnically diverse infants born within our Hospital.

\section{Materials and methods Subjects}

Sixty-two infants born at term (37-41 weeks of gestation), appropriate for gestational age (AGA), were enrolled. AGA was defined as a birth weight from 10th to 90th percentile for gestational age according to Italian charts [23]. All babies were born from vaginal delivery, after uncomplicated pregnancies and were otherwise healthy. None of the babies showed signs of distress at delivery.

Thirty-two infants were born to Italian mothers with very fair/fair skin and 30 to non-Caucasian mothers with dark skin: 10 with light olive/light brown and 20 with medium brown/black skin. Ten mothers were North African, 10 Central and Southern African, 5 Asian and 5 Latin American. North African mothers had light olive/ light brown skin, all others medium brown/black skin.

All newborns and their mothers were randomly enrolled within Division of Pediatrics, University of Piemonte Orientale, Novara, Italy from June to September 2009. The study protocol was approved by the responsible Ethics Committee of Novara and informed consent was obtained by newborn's parents before the sample collections.

All the mothers were healthy, in particular none had chronic diseases. Exclusion criteria were the presence of any organic diseases in particular neurological, endocrine, liver and kidney abnormalities in the mother or in the newborns.

Birth weight and length were recorded at birth by the attending nurse. All data was collected appropriately.

Newborns showed (mean \pm SD) a birth weight of $3252 \pm$ $426 \mathrm{~g}$, a length of $54.7 \pm 3 \mathrm{~cm}$ and a gestational age of $39.1 \pm 1.2$ weeks. All infants had an Apgar score of 8-10 points at 1 and 5 minutes. None had neonatal distress or intrapartum complications.

\section{Maternal supplementation}

The type and duration of maternal supplementation with Vitamin D was investigated during hospitalization. All mothers were considered adequately supplemented, with an intake of $400 \mathrm{IU}$ vitamin D per day as recommended by The Institute of Medicine.

All mothers had used daily a standard prenatal multivitamin containing 400 IU of vitamin D (vitamin D3), except for 4 mothers (2 times per day). Pure vitamin $\mathrm{D}$ preparations were not used in any case.

Twenty of 32 Italian mothers and 15 of 30 non Caucasian mother were supplemented during pregnancy. The average daily vitamin D intake was $420 \mathrm{IU} \pm 80 \mathrm{IU} / \mathrm{d}$ and the average duration of supplementation was $117 \pm 30$ days. All mothers assumed regularly the supplementation also in the last third trimester of pregnancy.

\section{Hormonal parameters}

25OHD was investigated in cord blood at delivery and in neonatal serum by venous blood sampling. Sampling was performed in the first three days of life during the neonatal metabolic screening.

25OHD levels $(\mathrm{ng} / \mathrm{ml})$ were measured by LIAISON ${ }^{\circledR}$, (DiaSorin, Inc, Stillwater, MN). The LIAISON $25 \mathrm{OH}$ Vitamin D TOTAL Assay uses chemiluminescent immunoassay 


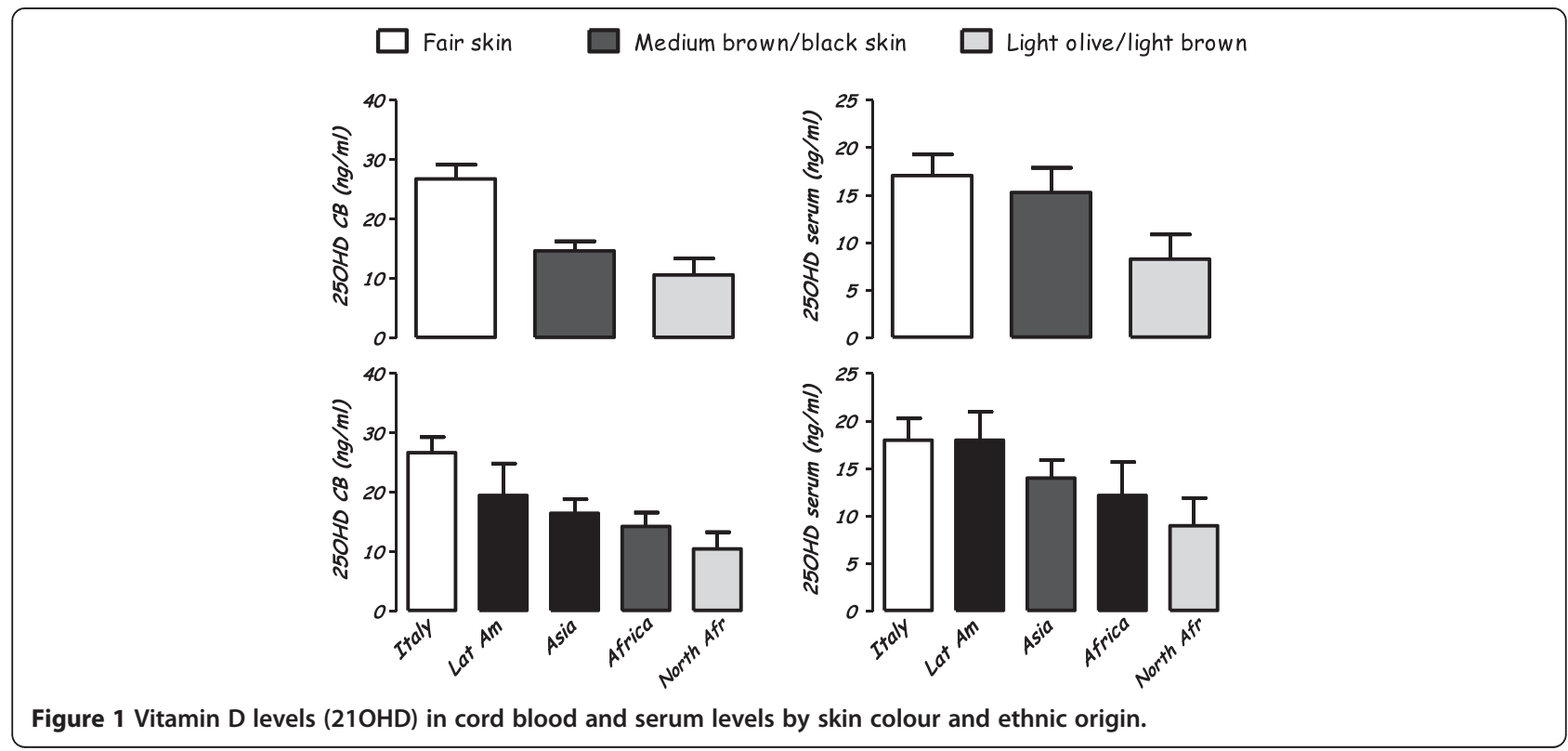

(CLIA) technology for the quantitative determination of 25OHD and other hydroxylated vitamin D metabolites in human serum. The analytical measurement range for the DiaSorin LIAISON $25 \mathrm{OH}$ Vitamin D Total Assay is $4 \mathrm{ng} /$ $\mathrm{mL}$ to $150 \mathrm{ng} / \mathrm{mL}$ and the sensitivity is $4 \mathrm{ng} / \mathrm{mL}$.

Data are expressed as mean \pm SD. For continuous variables, the variation between groups was compared by means on nonparametric Wilcoxon test. A correlation analysis was performed using the Pearson's correlation test with logarithmic transformations where necessary. A stepwise regression model with two-tailed probability values was used to measure the strength of association between variables. Statistical significance was assumed for $\mathrm{p}<0.05$. All statistical analyses were performed with SPSS for Windows version 17.0 (SPSS INC; Chicago, IL, USA).

\section{Results}

The mean vitamin D levels in all subjects were $21.4 \pm 11$ $\mathrm{ng} / \mathrm{ml}$ on cord blood and $14.9 \pm 7 \mathrm{ng} / \mathrm{ml}$ in neonatal serum.

$25 \mathrm{OHD}$ values were analysed by skin colour and by the mothers' country of origin (Figure 1). No sex differences were found.

In cord blood, $25 \mathrm{OHD}$ values were $<20 \mathrm{ng} / \mathrm{ml}$ in 30 cases (55.5\%): 18 (33.3\%) had mild vitamin D deficiency (between 10 and $20 \mathrm{ng} / \mathrm{ml}$ ) and $12(22.2 \%)$ had severe deficiency $(<10 \mathrm{ng} / \mathrm{ml})$.

In newborns, vitamin D levels were deficient $(<20 \mathrm{ng} /$ dl) in $75.6 \%$ of cases, with a severe deficiency $(<10 \mathrm{ng} /$ $\mathrm{ml})$ in $46.3 \%$ and a mild deficiency $(10-20 \mathrm{ng} / \mathrm{ml})$ in $29.3 \%$.
Analyzing exclusively infants born to immigrant mothers, none demonstrated 25OHD $>30 \mathrm{ng} / \mathrm{ml}$ in either cord blood or in neonatal serum. A deficiency in Vitamin D levels was found in the cord blood of $77.3 \%$ cases and in $81,8 \%$ of neonatal serum with a severe deficiency in $36,4 \%$ and $54,5 \%$, respectively.

When considering the maternal multivitamin intake during pregnancy, all mothers supplemented with vitamin D demonstrated higher 25OHD values in both cord blood $(24.5 \pm 11.9$ vs $17.2 \pm 9.2 \mathrm{ng} / \mathrm{ml} ; \mathrm{p}<0.01)$ and in neonatal serum $(17.7 \pm 9.3 \mathrm{vs} 11.1 \pm 6 \mathrm{ng} / \mathrm{ml} ; \mathrm{p}<0.001)$.

\section{OHD levels analysed by skin colour}

Vitamin D levels on cord blood were higher in neonates with fair skin (FS) than with dark skin $(\mathrm{p}<0.0001)$, both with light olive/light brown (LOB) $(\mathrm{p}<0.01)$ or medium brown/black skin (MBB) $(\mathrm{p}<0.01)$.

Three days after birth, newborns FS showed higher 25OHD levels only when compared with LOB $(\mathrm{p}<0.01)$.

Table 1 Vitamin D levels on cord blood (25OHD CB) and neonatal serum (25OHD $\mathrm{N}$ ) by skin colour

\begin{tabular}{|c|c|c|c|}
\hline & \multirow[t]{2}{*}{ FS } & \multicolumn{2}{|c|}{ Dark skin } \\
\hline & & $L O B$ & $M B B$ \\
\hline & 32 & 10 & 20 \\
\hline$G A$ & $38.8 \pm 1.1$ & $39.5 \pm 1.1$ & $39.5 \pm 1.2$ \\
\hline$B W$ & $3175 \pm 455$ & $3420 \pm 539$ & $3303 \pm 318$ \\
\hline $25 O H D C B$ & $26.8 \pm 13^{a, b}$ & $10.6 \pm 6.9^{a}$ & $14.7 \pm 6.2^{b}$ \\
\hline $250 H D N$ & $17.1 \pm 8^{a}$ & $8.3 \pm 4^{a, c}$ & $15.3 \pm 8^{c}$ \\
\hline
\end{tabular}

Abbreviations: $G A$ gestational age, $B W$ Birth weight, $F S$ very fair/fair skin, $L O B$ light olive/light brown, $M B B$ medium brown/black skin. a: $\mathrm{p}<0.01$ FS vs LOB; b: $p<0.01$ FS vs MBB; $c: p<0.02$ MMB vs LOB. 
Table 2 Vitamin D levels on cord blood (250HD CB) and neonatal serum (250HD N) according to maternal supplementation (S) in pregnancy

\begin{tabular}{|c|c|c|c|c|c|c|}
\hline & \multicolumn{2}{|c|}{ FS } & \multicolumn{2}{|c|}{$\angle O B$} & \multicolumn{2}{|c|}{$M M B$} \\
\hline & S 20 & No S 12 & S 5 & No S 5 & S 10 & No S 10 \\
\hline $250 H D C B$ & $29.2 \pm 11.4^{a, b}$ & $22.8 \pm 12^{\mathrm{a}, \mathrm{b}}$ & $11.9 \pm 6.8^{\mathrm{a}}$ & $4.2 \pm 0.5^{a}$ & $19.4 \pm 6.4^{b}$ & $11.9 \pm 5.4^{b}$ \\
\hline $250 H D N$ & $18.0 \pm 7.9$ & $15.9 \pm 9^{c}$ & $11.3 \pm 4.0$ & $4.2 \pm 0.3^{c}$ & $20.1 \pm 11$ & $8.2 \pm 2.3^{c}$ \\
\hline
\end{tabular}

Abbreviations: FS very fair/fair skin, $L O B$ light olive/light brown, $M B B$ medium brown/black skin, $S$ mothers supplemented with Vitamin D3, Non $S$ mothers not supplemented with Vitamin D3. $a: p<0.004$ FS vs LOB; $b: p<0.04$ FS vs MMB; $c$ : $<0.04$ FS vs LOB and MMB.

MBB had serum 25OHD values higher than LOB $(\mathrm{p}<0.02)$ without significant differences in cord blood (Table 1).

Differences according to maternal supplementation, were shown only in the MBB group $(\mathrm{p}<0.01)$ with higher vitamin $\mathrm{D}$ levels in cord blood and neonatal serum with supplementation. No differences with the FS and LOB groups were found.

In cord blood, 25OHD levels were higher in FS than LOB $(\mathrm{p}<0,004)$ and MBB $(\mathrm{p}<0.04)$ regardless of maternal supplementation.

Neonates FS with no supplementation during pregnancy, showed vitamin D levels higher than unsupplemented LOB and $\mathrm{MBB}$ neonates $(\mathrm{p}<0.05)$. No differences were found in case of maternal supplementation in pregnancy (Table 2).

\section{OHD levels analysed by mothers' country of origin}

The cord blood from italian newborns (ItaN), showed 25OHD levels higher than North African (NAN) $(\mathrm{p}<0.004)$ and African (AN) $(\mathrm{p}<0.01)$.

At three days of life, vitamin $\mathrm{D}$ values were higher in ItaN only when compared with NAN $(\mathrm{p}<0.03)$. NAN had 25OHD levels lower than AN $(p<0.02)$ without significant differences in cord blood levels.

No differences in Vitamin D levels were shown between ItaN and neonates born from Asian or Latin American mothers (Table 3).

\section{Correlations}

Vitamin D levels correlated in cord blood samples and neonatal serum ( $\mathrm{r}: 0.836, \mathrm{p}<0.0001)$, even when corrected for months, gestational age and birth weight.

Gestational age not correlated with cord blood vitamin D or neonatal serum levels.
Multiple regression analysis revealed that vitamin $\mathrm{D}$ levels in cord blood were predicted (R2: 0.670; $\mathrm{p}<0.0001$ ) by neonatal Vitamin $\mathrm{D}$ values (standardized $\beta$ : 0.818 ), when corrected for vitamin $\mathrm{D}$ supplementation and gestational age. Likewise neonatal vitamin $\mathrm{D}$ levels were predicted (R2: $0.670 ; p<0.0001)$ by Vitamin $D$ values on cord blood (standardized $\beta: 0.818$ ), when corrected for vitamin D supplementation and gestational age.

\section{Discussion}

The present study demonstrates a high prevalence of vitamin D deficiency and insufficiency both in cord blood and in neonatal serum, with lower concentrations in infants born from immigrant mothers.

Previous studies have shown a high prevalence of vitamin D deficiency among neonates and their mothers, particularly in United States, Australia, South Asia, the United Kingdom, Greece and in other European countries [24-29]. However, there is no absolute consensus on which is the normal range for 25OHD in newborns.

Analysing data by skin colour, we found that in cord blood, FS showed 25OHD levels higher than LOB or MBB neonates, while in neonatal serum FS had values higher only with respect to LOB, with no significant differences with MBB. LOB had lower serum levels with respect to $\mathrm{MBB}$, suggesting a particular role for different skin colour in metabolism and in vitamin D levels.

The two major sources of vitamin D in the body are diet and the skin. The different skin colour influences the vitamin D levels with the currently available data suggesting that plasma vitamin D was lower in black neonates than white neonates [8-11].

Table 3 Vitamin D levels on cord blood (250HD CB) and neonatal serum (250HD N) by mothers' country of origin

\begin{tabular}{|c|c|c|c|c|c|}
\hline & Italy & North Africa & Africa & Asia & Latin America \\
\hline & 32 & 10 & 10 & 5 & 5 \\
\hline$G A$ & $38.8 \pm 1.1$ & $39.5 \pm 1.1$ & $39.7 \pm 0.9$ & $38.8 \pm 1.6$ & $40 \pm 1.1$ \\
\hline$B W$ & $3175 \pm 455$ & $3420 \pm 539$ & $3425 \pm 300$ & $3039 \pm 244$ & $3291 \pm 279$ \\
\hline $25 O H D C B$ & $26.8 \pm 13^{a, b}$ & $10.6 \pm 6.9^{a}$ & $14.3 \pm 7^{b}$ & $16.5 \pm 4.9$ & $19.5 \pm 10$ \\
\hline $250 H D N$ & $17.1 \pm 8^{c}$ & $8.3 \pm 4^{c, d}$ & $14 \pm 5.7^{d}$ & $12.2 \pm 7$ & $19.3 \pm 10$ \\
\hline
\end{tabular}

Abbreviations: GA gestational age, $B W$ Birth weight; a: $p<0.004$ ITALY vs NORTH AFRICA; $b$ : $p<0.01$ ITALY vs AFRICA; c: $p<0.03$ ITALY vs NORTH AFRICA; $d: p<0.02$ AFRICA vs NORTH AFRICA. 
Analyzing data by mothers according to their country of origin, 25OHD cord blood levels were higher in neonates born from Italian mothers than from North African or African mothers, while after birth vitamin D serum levels were higher in Italian newborns only when compared with North African.

Other studies have shown results, similar to ours in that, 25OHD levels reflect racial origin. Sulaiman et al. [30], measured 25OHD levels in umbilical cord blood taken from 54 white and 22 south Asian neonates in the UK during summer, showing lower serum levels in South Asian $(19.8 \pm 22)$ infants, with respect to caucasians $(43.3 \pm 23 ; \mathrm{p}<0.0002)$. Recently, Dror et al. [31], showed mean serum vitamin $D$ levels were significantly lower in African-American than in non -African American women and their infants.

To achieve similar levels of $25 \mathrm{OHD}$, subjects with dark skin and consequent high-melanin content must be exposed to UVB light 4-5 times as long as individuals with white skin and low melanin content. Recently Sloka et al. [32] in Newfoundland, a Canadian island, showed a reduction of the solar radiation and a gradient of average daily UVB of $10,5 \%$ for a change of latitude from $46^{\circ} \mathrm{N}$ to $52^{\circ} \mathrm{N}$. Vitamin D insufficiency is common for latitudes north of $42^{\circ} \mathrm{N}$, which includes Novara.

Moreover, we observed higher vitamin D levels in cord blood than in neonate serum with a strong correlation to each other. During the first 2 months of life, neonatal and maternal 25OHD levels are correlated [16,33,34].

We have also investigated the role of supplementation in pregnancy on vitamin D cord blood and serum levels. Analyzing all subjects together, mothers supplemented with vitamin $\mathrm{D}$ showed $25 \mathrm{OHD}$ values higher than mothers not supplemented both on cord blood and neonatal serum. Analyzing the groups separately for skin colour, the supplementation seemed to determine significant differences only into MMB group with higher levels on cord blood and neonatal 25OHD serum in case of supplementation. No differences were found within FS and LOB group suggesting a probably different function of the supplementation according to skin colour.

Cord blood vitamin D levels were higher in FS than LOB or MBB regardless of supplementation. After birth only FS newborns unsupplemented showed vitamin D levels higher than LOB and MBB; no differences were found in case of maternal supplementation in pregnancy, most likely due to a specific role of supplementation in neonates.

The numbers were too small for a separate analysis into each ethnic groups.

Although several studies are available on vitamin D supplementation during pregnancy, its appropriate dose is not clear [19-21]. IOM recommends during pregnancy a dietary allowance of $600 \mathrm{IU} /$ day and an estimated average requirement of $400 \mathrm{IU} /$ day [6]. A recent Cochrane on vitamin D supplementation during pregnancy showed that with supplementation, there is an increase serum 25OHD levels in neonates [22].

Our study has several limitations. We lack of information on several potential confounders, in particular individual sun exposure and standardization of phototype. The skin colour has been evaluated, even if by the same person, only subjectively and not confirmed by Fitzpatrick Skin type chart, one of the objective methods of standardization. Moreover, vitamin D is influenced by seasonability and the study was conducted in a single season; however, the data was collected in summer when better vitamin $\mathrm{D}$ levels are demonstrated by literature [1]. Another important limitation is to have enrolled few Caucasian and non Caucasian subjects to perform a valid subanalysis according supplementation and country of origin. The current data is preliminary and is the basis of an ongoing study.

Further studies are necessary to understand what component is more important between skin colour and ethnicity.

\section{Conclusions}

The present study demonstrates a high prevalence of vitamin D deficiency and insufficiency both in cord blood and in neonatal serum with significant differences due to ethnicity, skin colour and presence or absence of supplementation. Identifying vitamin $\mathrm{D}$ deficiency at birth is essential for the development of public policy for prevention and supplementation.

\section{Abbreviations}

25OHD: Vitamin D; FS: Fair skin; LOB: Light olive/light brown skin:

MBB: Medium brown/black skin; ItaN: Italian Neonates; NAN: Neonates born by North African mothers; AN: Neonates born by African mothers.

\section{Competing interests}

The authors declare no conflict of interest. There is not conflict of interest that could be perceived as prejudicing the impartiality of the research reported.

\section{Authors' contributions}

Francesco Cadario participated in the study design and chose eligible patients. Savastio Silvia participated in the design of the study and carried out the samples analysis. Erica Pozzi participated in the design of the study and managed the literature search. Antonella Capelli participated in the design of the study and collected the samples. Elena Dondi participated in the design of the study and managed the literature searches. Miriam Gatto participated in the design of the study and carried out the samples analysis. Mauro Zaffaroni participated in the design of the study and helped to draft the manuscript. Gianni Bona conceived the study and participated in its coordination and helped to draft the manuscript. All authors read and approved the final manuscript.

Acknowledgements

The Authors wish to thank Dr Gillian Walker for English revision.

Received: 14 October 2012 Accepted: 30 May 2013

Published: 4 June 2013 


\section{References}

1. Holick MF, Binkley NC, Bischoff-Ferrari HA, Gordon CM, Hanley DA, Heaney RP, Murad MH, Weaver CM, Endocrine Society: Evaluation, Treatment, and Prevention of Vitamin D Deficiency: an Endocrine Society Clinical Practice Guideline. J Clin Endocrinol Metab 2011, 96(7):1911.

2. Baeke F, Takiishi T, Korf H, Gysemans C, Mathieu C: Vitamin D: Modulator of the immune system. Curr Opin Pharmacol 2010, 10:482-496.

3. Looker AC, Pfeiffer CM, Lacher DA, Schleicher RL, Picciano MF, Yetley EA: Serum 25-hydroxyvitamin D status of the US population: 1988-1994 compared to 2000-2004. Am J Clin Nutr 2008, 88:1519-1527.

4. Kumar J, Muntner P, Kaskel FJ, Hailpern SM, Melamed ML: Prevalence and associations of 25-hydroxyvitamin D deficiency in US children: NHANES 2001-2004. Pediatrics 2009, 124:362-370.

5. Lee JM, Smith JR, Philipp BL, Chen TC, Mathieu J, Holick MF: Vitamin D deficiency in a healthy group of mothers and newborn infants. Clin Pediatr (Phila) 2007, 46:42-44.

6. IOM (Institute of Medicine): Dietary Reference Intakes for Calcium and Vitamin D. Washington, DC: The National Academies Press; 2011.

7. Jones G: Pharmacokinetics of vitamin D toxicity. Am J Clin Nutr 2008, 88(2):582S-586S

8. Hollis $B W$, Wagner $C L$ : Vitamin D deficiency during pregnancy: an ongoing epidemic. Am J Clin Nutr 2006, 84:273.

9. Bodnar LM, Simhan HN, Powers RW, Frank MP, Cooperstein E, Roberts JM: High prevalence of vitamin D insufficiency in black and white pregnant women residing in the northern United States and their neonates. J Nutr 2007, 140(5):999-1006.

10. Van der Meer IM, Boeke AJ, Lips P, Grootjans-Geerts I, Wuister JD, Devillé WL, Wielders JP, Bouter LM, Middelkoop BJ: Fatty fish and supplements are the greatest modifiable contributors to the serum 25-hydroxyvitamin D concentration in a multiethnic population. Clin Endocrinol (Oxf) 2008, 68:466-472

11. Basile $L A$, Taylor $S N$, Wagner $C L$, Quinones $L$, Hollis BW: Neonatal vitamin D status at birth at latitude 32 degrees 72': evidence of deficiency. J Perinatol 2007, 27(9):568-571.

12. Holvik K, Meyer HE, Haug E, Brunvand L: Prevalence and predictors of vitamin D deficiency in five immigrant groups living in Oslo, Norway. The Oslo immigrant Health Study. Eur J Clin Nutr 2005, 59:57-63.

13. Looker AC, Dawson-Hughes B, Calvo MS, Gunter EW, Sahyoun NR: Serum 25-hydroxyvitamin $D$ status of adolescents and adults in two seasonal subpopulations from NHANES III. Bone 2002, 30(5):771-777.

14. Brock K, Wilkinson M, Cook R, Lee S, Bermingham M: Associations with Vitamin D deficiency in "at risk" Australians. I Steroid Biochem Mol Biol 2004, 89(1-5):581-588

15. Rockell JE, Green TJ, Skeaff CM, Whiting SJ, Taylor RW, Williams SM, Parnell WR, Scragg R, Wilson N, Schaaf D, Fitzgerald ED, Wohlers MW: Season and ethnicity are determinants of serum 25 -hydroxyvitamin $D$ concentrations in New Zealand children aged 5-14 y. J Nutr 2005, 135(11):2602-2608.

16. Clemens TL, Henderson SL, Adams JS, Holick MF: Increased skin pigment reduces the capacity of skin to synthesise vitamin D3. Lancet 1982, 319(8263):74-76

17. Mithal A, Wahl DA, Bonjour JP, Burckhardt P, Dawson-Hughes B, Eisman JA El-Hajj Fuleihan G, Josse RG, Lips P, Morales-Torres J: IOF Committee of Scientific Advisors (CSA): Nutrition Working Group: Global vitamin D status and determinants of hypovitaminosis D. Osteoporos Int 2009, 20(11):1807-1820.

18. Wagner $\mathrm{CL}$, Greer FR, and the Section on Breastfeeding and Committee on Nutrition: Prevention of Rickets and Vitamin D Deficiency in Infants, Children, and Adolescents. Pediatrics 2008, 122:1142-1152.

19. Datta S, Alfaham M, Davies DP, Dunstan F, Woodhead S, Evans J, Richards B: Vitamin $D$ deficiency in pregnant women from a non-European ethnic minority population-an interventional study. BJOG 2002, 109(8):905-908.

20. Madelenat $P$, Bastian $H$, Menn S: Winter supplementation in the 3rd trimester of pregnancy by a dose of 80,000 IU of vitamin D. J Gynecol Obstet Biol Reprod 2001, 30(8):761-767.

21. Kalra P, Das V, Agarwal A, Kumar M, Ramesh V, Bhatia E, Gupta S, Singh S, Saxena P, Bhatia V: Effect of vitamin D supplementation during pregnancy on neonatal mineral homeostasis and anthropometry of the newborn and infant. Br J Nutr 2012, 108(6):1052-1058.

22. De-Regil LM, Palacios C, Ansary A, Kulier R, Peña-Rosas JP: Vitamin D supplementation for women during pregnancy. Cochrane Database of
Systematic Reviews The Cochrane Collaboration: Published by John Wiley \& Sons, Ltd; 2012:1-61.

23. Bertino E, Spada E, Occhi L, Coscia A, Giuliani F, Gagliardi L, Gilli G, Bona G, Fabris C, De Curtis M, Milani S: Neonatal Anthropometric Charts: The Italian neonatal study compared with other European studies. JPGN 2010, 51:353-361.

24. Grover SR, Morley R: Vitamin D deficiency in veiled or dark-skinned pregnant women. Med J Aust 2001, 175:251-252.

25. Sachan A, Gupta R, Das V, Agarwal A, Awasthi PK, Bhatia V: High prevalence of vitamin $D$ deficiency among pregnant women and their newborns in northern India. Am J Clin Nutr 2005, 81:1060-1064.

26. Nicolaidou P, Hatzistamatiou Z, Papadopoulou A, Kaleyias J, Floropoulou E, Lagona E, Tsagris V, Costalos C, Antsaklis A: Low vitamin D status in mother-newborn pairs in Greece. Calcif Tissue Int 2006, 78:337-342.

27. Bassir M, Laborie S, Lapillonne A, Claris O, Chappuis MC, Salle BL: Vitamin D deficiency in Iranian mothers and their neonates: a pilot study. Acta Paediatr 2001, 90:577-579.

28. Pehlivan I, Hatun S, Aydogan M, Babaoglu K, Gokalp AS: Maternal vitamin $D$ deficiency and vitamin $D$ supplementation in healthy infants. Turk J Pediatr 2003, 45:315-320.

29. Serenius F, Elidrissy AT, Dandona P: Vitamin D nutrition in pregnant women at term and in newly born babies in Saudi Arabia. J Clin Pathol 1984, 37:444-447.

30. Sulaiman RA, Sharratt CL, Lee PW, Skinner A, Griffiths MJ, Webster C, Ford C, Anderson J, Gama R: Ethnic differences in umbilical cord blood vitamin D and parathyroid hormone-South Asians compared to Whites born in the UK. J Matern Fetal Neonatal Med 2010, 23(11):1315-1317.

31. Dror DK, King JC, Fung EB, Van Loan MD, Gertz ER, Allen LH: Evidence of associations between feto-maternal vitamin $D$ status, cord parathyroid hormone and bone-specific alkaline phosphatase, and newborn whole body bone mineral content. Nutrients 2012, 4(2):68-77.

32. Sloka S, Grant M, Newhook LA: The geospatial relation between UV solar radiation and type 1 diabetes in Newfoundland. Acta Diabetol 2010, 47(1):73-78.

33. Holick MF, Chen TC: Vitamin D deficiency: a worldwide problem with health consequences. Am J Clin Nutr 2008, 87(suppl):1080S-1086S.

34. Eyles DW, Morley R, Anderson C, Ko P, Burne T, Permezel M, Mortensen PB, Nørgaard-Pedersen B, Hougaard DM, McGrath JJ: The utility of neonatal dried blood spots for the assessment of neonatal vitamin D status. Paediatr Perinat Epidemiol 2010, 24(3):303-308.

doi:10.1186/1824-7288-39-35

Cite this article as: Cadario et al:: Vitamin D status in cord blood and newborns: ethnic differences. Italian Journal of Pediatrics 2013 39:35.

\section{Submit your next manuscript to BioMed Central and take full advantage of:}

- Convenient online submission

- Thorough peer review

- No space constraints or color figure charges

- Immediate publication on acceptance

- Inclusion in PubMed, CAS, Scopus and Google Scholar

- Research which is freely available for redistribution 